\title{
Studies on N-metabolism in different gastro- intestinal sections of sheep using the digesta exchange technique. 4 . Whole body protein metabolism ${ }^{*}$
}

\author{
A. Sandek ${ }^{1}$, K. Krawielitzki ${ }^{2}$, J. Kowalczyk ${ }^{3}$, M. Gabel ${ }^{1}$, \\ T. Żebrowska ${ }^{3}$, F. Kreienbring ${ }^{2}$, H. Hagemeister ${ }^{4}$ and J. Voigt ${ }^{4.5}$ \\ 'Institute for Ecologically-Compatible Animal Husbandry, University of Rostock \\ Justus-von-Liebig-Weg 8. 18059 Rostock, Germany \\ 'Institute for Applied Agroecology, Justus-von-Liebig Weg 8.18059 Rostock, Germany \\ 'The Kielanowski Institute of Animal Physiology and Nutrition. Polish Academy of Sciences \\ 05-110 Jablonna, Poland \\ ${ }^{4}$ Research Institute for the Biology of Farm Animals, \\ Research Unit Nutritional Physiology "Oskar Kellner" \\ Wilhelm-Stahl-Allee 2, 18196 Dummerstorf, Germany
}

(Received 12 September 2002; accepted 11 October 2002)

\section{ABSTRACT}

Parameters of protein turnover were measured in sheep differing in postruminal secretion and reabsorption of nitrogen. The experiments were carried out with Polish Merino sheep (20-25 kg BW) fitted with rumen and re-entrant cannulas at the duodenum and the ileum. Two groups of animals $(n=9)$ were fed with diets that were nearly isonitrogenous but differed in crude fibre (CF) content (CF in \% dry matter (DM): Group 1, 14.7. Group 2, 24.9). $\Lambda$ s a result of the higher CF content, the intake of DM was lower in Group 2 than in Group $1\left(616 \mathrm{vs} 467 \mathrm{~g} \mathrm{x} \mathrm{d}^{-1}\right)$. In all carried out cxperiments (Sandek et al., 2001a) one of the three animals (No 1) was labelled with ${ }^{15} \mathrm{~N}$ by intraniminal infusion of ${ }^{5} \mathrm{~N}$ urea. Then duodenal digesta of this labelled animal was exchanged with digesta of an unlabelled animal (No 2) during a $48 \mathrm{~h}$ period. The $\mathrm{N}$ - and ${ }^{15} \mathrm{~N}$ flow through the intestinal tract, the $\mathrm{N}$ and ${ }^{15} \mathrm{~N}$ excretion in faeces and urine as well as the absorption rates were estimated in animal No 2 during that period. Using these data, kinetic parameters of protein turnover were calculated using the end-product method and the 3-compartment model.

\footnotetext{
* Supported by the Deutsche Forschungsgemeinschaft (DFG), H. Wilhelm Schaumann Stiftung and the State Committee for Scientific Rescarch (Polish)

${ }^{5}$ Corresponding author; e-mail: voigt@fbn-dummerstorf.de
} 
Intake of $\mathrm{N}$ (16.1 vs $11.7 \mathrm{~g} \mathrm{x} \mathrm{d}^{-1}$ in Groups 1 and 2), net $\mathrm{N}$ absorption (12.3 vs $7.3 \mathrm{~g} \mathrm{x} \mathrm{d}^{-1}$ ) and $\mathrm{N}$ balance ( $\left.104 \mathrm{vs}-56 \mathrm{mg} \times \mathrm{kg} \mathrm{BW}^{-1} \times \mathrm{d}^{-1}\right)$ were higher in Group $1(\mathrm{P}<0.10)$. No difference were found in flux (1666 vs $1458 \mathrm{mg} \mathrm{N} \times \mathrm{kg} \mathrm{BW}^{-1} \mathrm{x} \mathrm{d}^{-1}$ ), synthesis (1238 vs $1087 \mathrm{mg} \mathrm{N} \mathrm{x} \mathrm{kg} \mathrm{BW-1} \mathrm{x} \mathrm{d}^{-1}$ ) or breakdown (1134 vs $\left.1324 \mathrm{mg} \mathrm{N} \mathrm{x} \mathrm{kg} \mathrm{BW} \mathrm{x} \mathrm{d}^{-1}\right)$ of protein. However, the efficiency of protein synthesis ( $\mathrm{N}$ balance/synthesis $\mathrm{x} 100$ ) was significantly higher in (jroup 1 ( 8.8 vs $-5.2 \% ; \mathrm{P}<0.10)$. The efficiency of protein synthesis correlated negatively with $N$ secretion in the postruminal tract $(r=-0.99$; $\mathrm{P}<0.001)$ and with ileal flow of endogenous $\mathrm{N}(\mathrm{r}=-0.95 ; \mathrm{P}<0.01)$. In conclusion, a high intestinal $\mathrm{N}$ secretion adversely affects the efficiency of whole body protein synthesis in growing sheep.

KEY WORDS: whole body protein turnover, intestinal $\mathrm{N}$ secretion, efficiency of protein synthesis, ${ }^{15} \mathrm{~N}$

\section{INTRODUCTION}

Protein retention in the tissue of growing animals or humans is the result of two opposing, dynamic processes: protein synthesis and protein breakdown. Determination of such kinetic parameters of protein turnover as synthesis and breakdown may be of importance for animal as well as for human nutrition and enable to optimize protein gain or minimizing protein loss during growth. The efficiency of protein synthesis, i.e. the proportion of synthesized protein which is deposited, is considerably lower in the whole body than in some organs, e.g. muscles (Simon, 1989).

The reason for this are the much higher protein synthesis rates and low protein deposition rates in organs like liver or gastrointestinal tract. Secretion and partial reabsorption of protein in the gastrointestinal tract are part of whole body protcin turnover. However, the secreted and excreted proteins are not measured as protein deposition. It can thus be assumed that protein secretion and the efficiency of whole body protein synthesis are related. Therefore the aim of this experiment was to study the whole body protein turnover in growing sheep differing in gastrointestinal secretion and reabsorption of nitrogenous compounds.

The experiments were carried out to estimate parameters of $\mathrm{N}$ metabolism in different gastrointestinal sections of sheep using the digesta exchange technique between ${ }^{15} \mathrm{~N}$ labelled-and unlabelled animals (Sandek et al., 2001a,b, 2002). The data of $\mathrm{N}$ balances and ${ }^{15} \mathrm{~N}$ balances estimated during the exchange periods were used to calculate the parameters of $\mathrm{N}$ kinetics.

\section{MATERIAL AND METHODS}

\section{Animals and experimental design}

Eighteen shecp (Polish Merino, 20-25 kg BW), fitted with rumen and re-entrant cannulas in the proximal duodenum and the distal ileum were divided in two groups. Group 1 (Experiments $1-3$ ) received a ration containing $14.7 \mathrm{~g}$ crude fibre (CF)/ $100 \mathrm{~g}$ dry matter (DM), $16.3 \mathrm{~g}$ crude protein (CP) $100 \mathrm{~g}$ DM, and $11 \mathrm{MJ} \mathrm{ME} / \mathrm{kg}$ DM, whereas Group 2 (Experiments 4-6) was fed a ration containing $24.9 \mathrm{~g} \mathrm{CF} / 100 \mathrm{~g} \mathrm{DM}, 15.7 \mathrm{~g} \mathrm{CP} / 100 \mathrm{~g}$ 
$\mathrm{DM}$, and $10 \mathrm{MJ} \mathrm{ME} / \mathrm{kg} \mathrm{DM}$. The DM intake was $616 \mathrm{~g} \mathrm{x} \mathrm{d}^{-1}$ and $467 \mathrm{~g} \mathrm{x} \mathrm{d}^{-1}$ in Group 1 and Group 2, respectively. The diets were offered as six meals per day.

Three sheep were included in each experiment. One of the three sheep (No 1) was labelled by continuous intraruminal infusion of $1 \mathrm{~g}{ }^{15} \mathrm{~N}$ urea $(95$ atom $\%$, VEB Berlin-Chemie, Berlin, Germany) per day. After a 6-day labelling period the ${ }^{15} \mathrm{~N}$-labelled duodenal digesta of these animals was exchanged against the digesta of an unlabelled animal via the duodenal cannulas, so that the ${ }^{15} \mathrm{~N}$-labelled digesta passed into the digestive tract of animal No 2. During the two day digesta exchange period, whole body $\mathrm{N}$ balance as well as ${ }^{15} \mathrm{~N}$ balance along the digestive tract of the animal were estimated. Using the end-product method and the 3-pool model of Sprinson and Rittenberg (1949) modified by Krawielitzki et al. (1989) these data were used to calculate the turnover rates of whole body protein metabolism. At the end of each experiment, the animais were slaughtered and the $\mathrm{N}$ content in whole body was estimated. For this purpose, the body was homogenised and the total $\mathrm{N}$ was estimated by the Kjeldahl procedure. More information on experimental design, materials and methods used is given in detail by Sandek et al. (2001a,b, 2002).

\section{Three-pool model and calculation of $N$ turnover}

The 3-pool model used (Figure 1) is based on the assumption that the metabolism of the tracer $\left({ }^{15} \mathrm{~N}\right)$ represents the metabolism of total $\mathrm{N}$. The amount of ${ }^{15} \mathrm{~N}$ is divided between protein synthesis and protein oxidation followed by urinary $\mathrm{N}$ excretion.

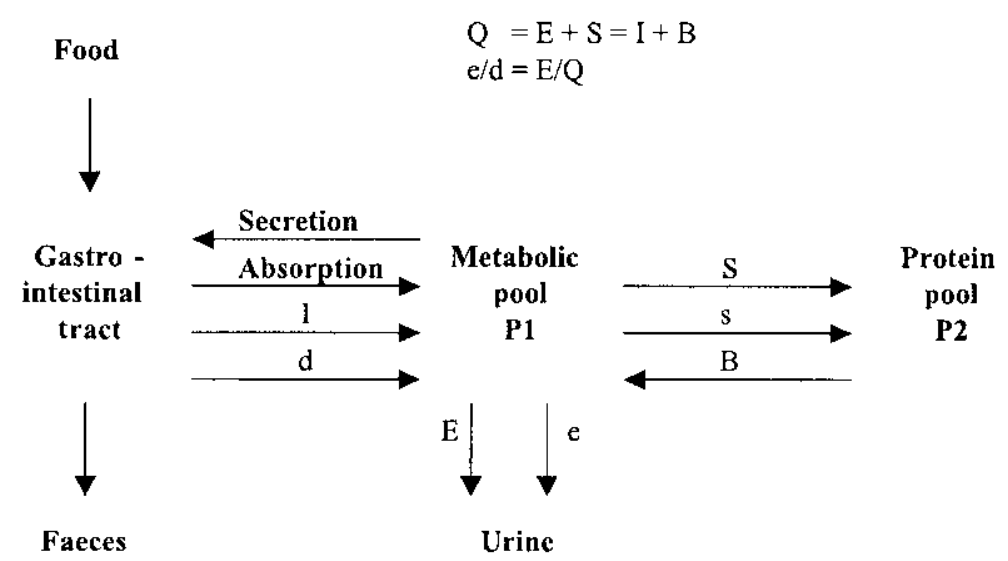

Figure 1. Model of protein turnover (Sprinson and Rittenberg, 1949, modified by Krawielitzki et al., 1989)

Q - N flux; I - net N absorption; E - urinary N excretion; S - protein syntluesis; B - protein breakdown; $\mathrm{d}$ - postruminal absorbed ${ }^{15} \mathrm{~N}$; e $-{ }^{15} \mathrm{~N}$ excretion in urine; $\mathrm{s}-{ }^{15} \mathrm{~N}$ incorporated in protein 
Further assumptions for this model are that 1) during the measurement period no recycling of the tracer from the protein pool back into the metabolic pool occurs, 2) pool size and flow rates are constant, and 3) other pathways of the intermediate $\mathrm{N}$ metabolism except protein synthesis, breakdown, and oxidation followed by excretion are negligible.

During passage of the digesta through the small and the large intestine of animal No 2, most of the ${ }^{15} \mathrm{~N}$ administered by digesta exchange at the duodenum will be $\mathrm{ab}$ sorbed. One part of this absorbed ${ }^{15} \mathrm{~N}\left({ }^{15} \mathrm{~N}\right.$ dose, $\left.d\right)$ will be excreted in urine $\left({ }^{15} \mathrm{~N}\right.$ excretion, $\ell$ ), the other part will be used for synthesis of body protein $\left({ }^{15} \mathrm{~N}\right.$ protein synthesis, s). Thus, the ${ }^{15} \mathrm{~N}$ flux (q) entering or leaving the metabolic pool is defined as:

$$
\begin{aligned}
q\left[\mathrm{mg}^{15} \mathrm{Nx} \mathrm{d}^{-1}\right] & =d\left[\mathrm{mg}^{15} \mathrm{Nx} \mathrm{d}^{-1}\right]=e\left[\mathrm{mg}^{15} \mathrm{~N} \mathrm{x} \mathrm{d}^{-1}\right]+s\left[\mathrm{mg}^{15} \mathrm{Nx} \mathrm{d}^{-1}\right] \\
{ }^{15} \mathrm{~N} \text { flux } & ={ }^{15} \mathrm{~N} \text { output }
\end{aligned}
$$

Using the 3-pool model (Figure 1), knowing the urinary $\mathrm{N}$ excretion (E) and the quotient of $d / e$ enable the calculation of $\mathrm{N}$ flux (Q), which is the sum of all $\mathrm{N}$ fluxes entering or leaving the metabolic pool:

$$
\mathrm{Q}\left[\mathrm{gNx} \mathrm{d}^{-1}\right]=\mathrm{E}\left[\mathrm{gNxd}^{-1}\right] \times \mathrm{d} / e
$$

The ${ }^{15} \mathrm{~N}$ dose $d$ and the urinary ${ }^{15} \mathrm{~N}$ excretion rate $e$ are both estimated in animal No 2 for each experiment. The amounts of $\mathrm{E}$ and the net-N absorption $\mathrm{I}(\mathrm{I}=\mathrm{N}$ intake - $\mathrm{N}$ facces) are calculated as the average of all three animals (No 1,2,3) of the individual experiments.

The rates of synthesis (S) and breakdown (B) for whole body protein can be estimated from the following equation (Waterlow et al., 1978):

$$
\begin{aligned}
& Q\left[\mathrm{gNxd}^{-1}\right]=I\left[\mathrm{gNx} \mathrm{d}^{-1}\right]+\mathrm{B}\left[\mathrm{gNxd}^{-1}\right]=\mathrm{E}\left[\mathrm{gNxd^{-1 }}\right]+\mathrm{S}\left[\mathrm{gNx \textrm {N } ^ { - 1 }}\right] \\
& \mathrm{N} \text { flux }=\mathrm{N} \text { input }=\quad \mathrm{N} \text { output }
\end{aligned}
$$

The reutilization rate $(\mathrm{R})$ which represents that part of the breakdown of $\mathrm{N}$ or AA used for more synthesis of body protein, can be computed as follows:

$$
\mathrm{R}[\%]=100 \times \mathrm{S}\left[\mathrm{g} \mathrm{Nx} \mathrm{d}^{-1}\right] / \mathrm{Q}\left[\mathrm{g} \mathrm{N} \mathrm{x} \mathrm{d}^{-1}\right]
$$

Statistical analyses

$\mathrm{N}$ balance and $\mathrm{N}$ turnover data were subjected to analysis of variance using the one-factorial ANOVA procedure of SPSS (SPSS Inc., Vers. 10.07) at a $90 \%$ significance level. All results are expressed as means \pm SEM. Linear regression analysis to analyse the relation between efficiency of protein synthesis and $\mathrm{N}$ secretion was done with the same software package. 


\section{RESULTS}

The largest part of intraruminally ${ }^{15} \mathrm{~N}$ administered as urea was absorbed during the passage up to the proximal duodenum $(54 \pm 4.4 \%)$. The remaining amount was largely incorporated in microbial protein, which amounted to about $40 \%$ of the total digesta $\mathrm{N}$ passing to the duodenum. This ${ }^{15} \mathrm{~N}$ labelled duodenal digesta of animal No 1 was exchanged against the unlabelled digesta of animal No 2 and passed the postruminal digestive tract of unlabelled animal No 2 up to excretion by the faeces.

The amounts of ${ }^{15} \mathrm{~N}$ entering the duodenum with digesta to animal No 2, passing through the ileum, and excreted with faeces and urine, respectively, are shown for five experiments in Table 1. Data obtained for Experiment 3 (Group 1) were eliminated from calculations because the duodenal cannula in one of the animals was placed incorrectly.

TABLE 1

Parameters of intraruminal infusion and duodenal flow of ${ }^{15} \mathrm{~N}$ of animals No 1 and flow and absorption of ${ }^{15} \mathrm{~N}$ along various sections of the gastrointestinal tract of animals No $2\left(\mathrm{mg} \mathrm{x} \mathrm{d}^{-1}\right)$ fed a low (Group 1) or high (Group 2) fibre diet'

\begin{tabular}{|c|c|c|c|c|c|}
\hline \multirow{2}{*}{ 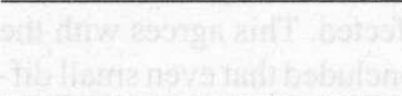 } & \multicolumn{2}{|c|}{ Group 1} & \multicolumn{3}{|c|}{ Group 2} \\
\hline & Exp. 1 & Exp. 2 & Exp. 4 & Exp. 5 & Exp. 6 \\
\hline \multicolumn{6}{|l|}{ Animal No 1} \\
\hline intraruminal infusion & 460.4 & 460.4 & 460.4 & 460.4 & 460.4 \\
\hline duodenal flow & 251.7 & 181.8 & 187.3 & 270.9 & 173.8 \\
\hline \multicolumn{6}{|l|}{ Animal No 2} \\
\hline duodenal input & 244.1 & 176.4 & 181.7 & 261.8 & 168.6 \\
\hline ileal flow & 66.6 & 65.6 & 68.2 & 105.1 & 60.3 \\
\hline small intestinal absorption & 177.5 & 110.8 & 113.5 & 156.7 & 108.3 \\
\hline ileal input & 64.6 & 63.6 & 66.1 & 101.9 & 58.5 \\
\hline faecal excretion & 38.0 & 31.9 & 29.4 & 45.5 & 34.9 \\
\hline large intestinal absorption & 26.6 & 31.7 & 36.7 & 56.4 & 23.6 \\
\hline postruminal absorption (d) & 204.1 & 142.5 & 150.2 & 213.1 & 131.9 \\
\hline . & & & & & (n) \\
\hline Urinary excretion (e) & 58.3 & 32.4 & 34.5 & 61.7 & 33.0 \\
\hline$d / e$ & 3.5 & 4.4 & 4.4 & 3.4 & 4.0 \\
\hline
\end{tabular}

for details see text and Sandek et al. (2001a,b, 2002)

The apparent postruminal ${ }^{15} \mathrm{~N}$ digestibility for both groups amounted to about $80 \%$. Two thirds of the ${ }^{15} \mathrm{~N}$ was absorbed in the small and one third in the large intestine, respectively. The ratio of intestinal absorbed ${ }^{15} \mathrm{~N}$ to urinary excreted ${ }^{15} \mathrm{~N}(d / e)$ was identical for both groups (Group 1, 3.95 \pm 0.45 ; Group 2, 3.93 \pm 0.29 ), indicating that three quarters of the ${ }^{15} \mathrm{~N}$ dose absorbed during passage along the intestine was used for synthesis of body protein while the residual was directed to urinary excretion. 
In comparison with Group 2, intake of $\mathrm{N}$, net $\mathrm{N}$ absorption and $\mathrm{N}$ balance were significantly higher in Group $1(\mathrm{P}<0.10$; Table 2$)$. No difference could be observed in $\mathrm{N}$ flux, protein synthesis, protein breakdown or in the reutilization rate of $N$. However, the fractional growth rate (FGR) and the efficiency of protein synthesis $(\mathrm{N}$ balance/synthesis $\times 100)$ were significantly greater in Group $1(\mathrm{P}<0.10)$. In this Group fed a diet with a lower $\mathrm{CF}$ content, $\mathrm{N}$ secretion in the small intestine was significantly $(\mathrm{P}<0.10)$ lower than in Group 2 given a diet with a higher $\mathrm{CF}$ content (9.4 vs $16.0 \mathrm{~g} \mathrm{~N} \mathrm{x} \mathrm{kg} \mathrm{DMI}^{-1}$; Sandek et al., 2002).

\section{DISCUSSON}

Nitrogen retention or protein gain was significantly different between the groups $(\mathrm{P}<0.10)$. Ulbrich $(1988)$ also found a negative influence of dietary crude fibre on protein gain in growing lambs. This gain is the result of protein synthesis and protein breakdown. The question is whether this lower $\mathrm{N}$ retention of Group 2 results from a reduced protein synthesis and/or an enhanced breakdown. Both synthesis and, in particular, breakdown of protein were insignificantly affected. This agrees with the findings of Davis et al. (1981) and Lobley (1993), who concluded that even small differences in protein synthesis or degradation result in large changes in protein gain.

The dynamic of intermediate protein metabolism is particularly demonstrated by the high synthesis rate, which was ten-fold that of the protein $\mathrm{N}$ gain in Group 1. Waterlow et al. (1978), Davis et al. (1981), Pahle et al. (1981) and Attaix et al. (1987) used a similar method to show that protein synthesis exceeds many-fold the amount of $\mathrm{N}$ gain.

Unfortunately, in this study a significant difference exists in the intake of DM and therefore in the consumption of $\mathrm{N}$ and energy. The net $\mathrm{N}$ absorption (I) in Group 1 $(12.3 \mathrm{~g} \mathrm{~N} / \mathrm{d})$ was higher than that of Group $2(7.3 \mathrm{~g} \mathrm{~N} / \mathrm{d})$, due to the smaller DM intake of this Group (Table 2). Despite the lower $\mathrm{N}$ absorption and energy intake in Group 2, protein synthesis was only marginally decreased and protein degradation was equivalent. This suggests that factors other than $\mathrm{N}$ and energy intakes affect protein turnover.

As shown in Figure 2, there is a significant negative relation between the efficiency of protein synthesis and $\mathrm{N}$ secretion in the postruminal tract $(\mathrm{r}=-0.99)$ or the ilcal flow of endogenous $N(\mathrm{r}=-0.95)$. Hence, it can be concluded that the processes of postruminal $\mathrm{N}$ secretion and reabsorption influence whole body protein turnover significantly. Part of the total synthesized protein is secreted into the intestinal tract. The secretion and reabsorption of protein in the intestine are part of whole body protein tumover and cause unavoidable protein losses for maintenance.

The calculation of the kinetic parameters for protein metabolism using the pool model is correct only if the metabolic pool is homogenous, containing chemically 


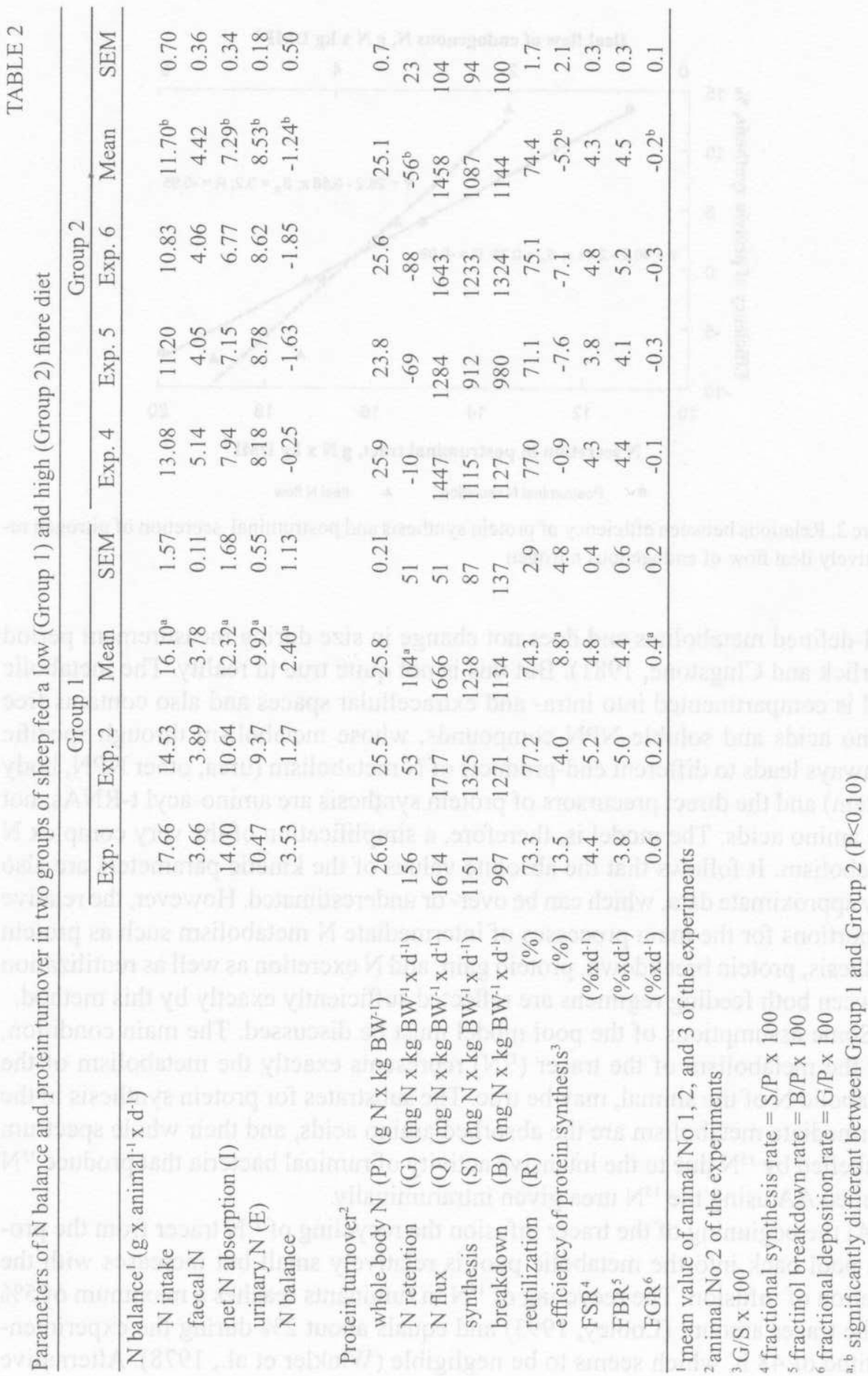




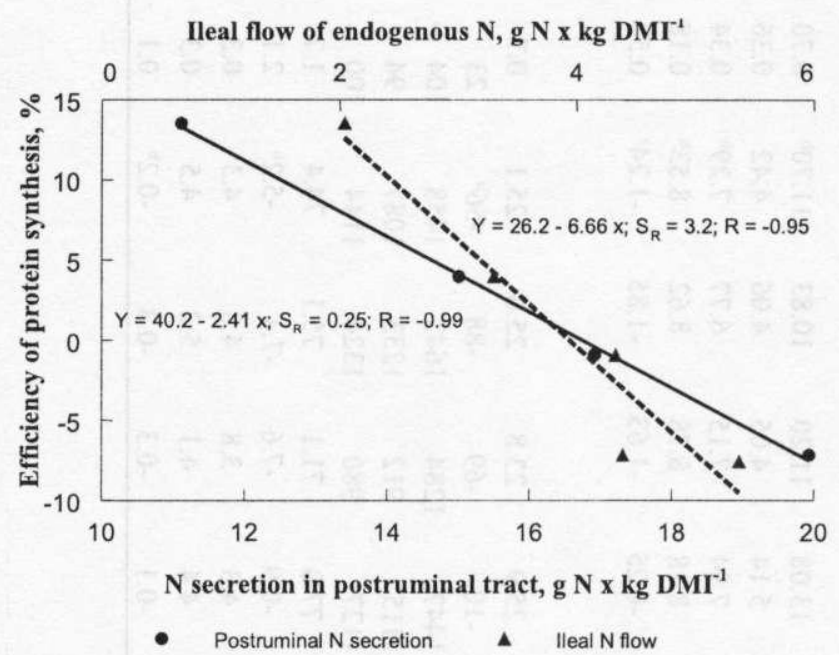

Figure 2. Relations between efficiency of protein synthesis and postruminal secretion of nitrogen respectively ileal flow of endogenous nitrogen

well-defined metabolites and does not change in size during measurement period (Garlick and Clugstone, 1981). But this is not quite true in reality. The metabolic pool is compartmented into intra- and extracellular spaces and also contains free amino acids and soluble NPN compounds, whose metabolism through specific pathways leads to different end-products of N metabolism (urea, other NPN, body protein) and the direct precursors of protein synthesis are amino-acyl t-RNAs, not free amino acids. The model is, therefore, a simplification of the very complex $\mathrm{N}$ metabolism. It follows that the absolute values of the kinetic parameters are also only approximate data, which can be over- or underestimated. However, the relative proportions for the main processes of intermediate $\mathrm{N}$ metabolism such as protein synthesis, protein breakdown, protein gain, and $\mathrm{N}$ excretion as well as reutilization between both feeding regimens are reflected sufficiently exactly by this method.

Some assumptions of the pool model must be discussed. The main condition, that the metabolism of the tracer $\left({ }^{15} \mathrm{~N}\right)$ represents exactly the metabolism of the metabolic $\mathrm{N}$ of the animal, may be true. The substrates for protein synthesis in the intermediate metabolism are the absorbed amino acids, and their whole spectrum is labelled by ${ }^{15} \mathrm{~N}$ due to the intensive activity of ruminal bacteria that produce ${ }^{15} \mathrm{~N}$ labelled AA using the ${ }^{15} \mathrm{~N}$ urea given intraruminally.

At the beginning of the tracer infusion the recycling of ${ }^{15} \mathrm{~N}$ tracer from the protein pool back into the metabolic pool is relatively small but increases with the duration of infusion. The recycling of ${ }^{15} \mathrm{~N}$ in ruminants reaches a maximum of $5 \%$ of the tracer amount (Lobley, 1993) and equals about 2\% during the experimental time of $48 \mathrm{~h}$, which seems to be negligible (Winkler et al., 1978). Alternative 
pathways other than protein synthesis, breakdown, and oxidation are limited to 5\% of the $\mathrm{N}$ flux and the flow rates from one pool to another oscillate during the day. Because of the short $4 \mathrm{~h}$ feeding intervals in this experiment it is assumed that the influence of alternative pathways is small.

\section{CONCLUSIONS}

In conclusion, the efficiency of whole body protein synthesis is significantly negatively influenced by $\mathrm{N}$ secretion in the postruminal tract. The higher the intestinal $\mathrm{N}$ secretion, the lower the efficiency of protein synthesis ( $\mathrm{N}$ balance/synthesis). The $\mathrm{N}$ secretion is stimulated by dietary factors, like crude fibre content (Sandek et al., 2002) or intestinal passage of NDF (Żebrowska and Kowalczyk, 1991; LammersWienhoven et al., 1998). Under practical feeding conditions this loss by $\mathrm{N}$ secretion should be take into account in protein evaluation systems for ruminants as indirectly done in the energy evaluation systems with the factor $q$ (Van Es, 1975).

\section{ACKNOWLEDGEMENTS}

The authors are grateful to Christa Schwarzat, Lilli Riede, Elisabeth Krawielitzki, for their technical assistance. It is a pleasure to acknowledge the constructive criticism of the manuscript by Cornelia C. Metges.

\section{REFERENCES}

Attaix D., Aurousseau E., Bayle G., Arnal M., 1987. Protein synthesis and degradation in growing lambs. Wiss. Z. WPU Rostock, N-Reihe 36 (10), 24-25

Davis S.R., Barry, T.N., Hughson G.A., 1981. Protein synthesis in tissues of growing lambs. Brit. J. Nutr. 46, 409-419

Garlick P.J., Clugstone G.A., 1981. Measurement of whole body protein turnover by constant infusion of carboxyl-labelled leucine. In: J.C. Waterlow, J.W.L. Stephen (Editors). Nitrogen Metabolism in Man. London, New Jersey, Appl. Sci. Publ., pp. 303-322

Krawielitzki K., Schadereit R., Wünsche J., 1989. Methodische Empfehlungen zur Bestimmung von Gesamtkörper-Proteinsyntheseraten im Tracerversuch. Arch. Anim. Nutr. 10, 799-811

Lammers-Wienhoven S.C.W., Voigt J., Ram L., Van Bruchem J., Ketelaars J., Tamminga S., 1998. Effect of cell walls, dry matter and protein supply on endogenous nitrogen flow in the small intestine of sheep. J. Anim. Physiol. Anim. Nutr. 79, 225-236

Lobley G.E., 1993. Protein metabolism and turnover. In: J.M. Forbes, J. France (Editors). Quantitative Aspects of Ruminant Digestion and Metabolism. CAB International, pp. 313-339

Pahle T., Kölıler R., Gebhardt G., Souffrant W.B., Ruhe C., 1981. On the N-metabolism and its modelling as a result of rat experiments with ${ }^{15} \mathrm{~N}$-labelled wheat. Arch. Tierernähr. 31, 127-140 
Sandek A., Krawielitzki K., Kowalczyk J., Kreienbring F., Gabel M., Żebrowska T., Voigt J., 2001 a. Studies on $\mathrm{N}$-metabolism in different gastro-intestinal sections of sheep using the digesta exchange technique.1. Model and experimental conditions. J. Anim. Feed Sci. 10, 421-434

Sandek A., Krawielitzki K., Kowalczyk J., Kreienbring F., Schönhusen U., Gabel M., Żebrowska T., Hagemeister H., Voigt J., 2001b. Studies on N-metabolism in different gastro-intestinal sections of sheep using the digesta exchange technique. 2. Passage of endogenous nitrogen. J. Anim. Feed Sci. 10, 605-618

Sandek A., Krawielitzki K., Kowalczyk J., Kreienbring F., Gabel M., Schönhusen U., Żebrowska T., Hagemeister, H., Voigt J., 2002. Studies on N-metabolism in different gastro-intestinal sections of sheep using the digesta exchange technique. 3. Secretion and reabsorption. J. Anim. Feed Sci. $11,277-288$

Simon O., 1989. Metabolism of proteins and amino acids. In: H.-D. Bock., B.O. Eggum, A.G. Low, O. Simon, T. Żebrowska (Editors). Protein Metabolism in Farm Animals. Oxford University Press, pp. 273-366

Sprinson D.B., Rittenberg D., 1949. The rate of interaction of the amino acids of the diet with the tissue proteins. J. Biol. Chem. 180, 715-726

Ulbrich M., 1988. Protein synthesis of growing lambs. Wiss. Z. WPU. Rostock, N-Reihe 37 (2), 77

Van Es A.J.H., 1975. Feed evaluation for dairy cows. Livest. Prod. Sci. 2, 95-107

Waterlow J.C., Garlick P.J., Millwardt D.J., 1978. Protein Turnover in Mammalian Tissues and in Whole Body. North-Holland Publishing Company, Amsterdam

Winkler E., Faust H., Wetzel K., Czarnetzky H.-D., Hartig W., 1978. Theoretische Aspekte der Untersuchung des Stickstoffmetabolismus. 2. Probleme der Auswertung und Interpretation klinischer Untersuchungen. Isotopenpraxis 14, 367-37

Żebrowska T., Kowalczyk J., 1991. Nitrogen secretion into isolated loops of the small intestine in conscious sheep. J. Anim. Physiol. Anim. Nutr. 65, 133-139

\section{STRESZCZENIE}

Badania nad przemianą azotu w różnych odcinkach przewodu pokarmowego owiec przy zastosowaniu metody „wymiany treści”. 4. Metabolizm bialka w calym ciele owiec

Oznaczano parametry obrotu białka w organizmie owiec różniących się rozmiarem sekrecji i wchłaniania azotu w jelicie. Doświadczenia wykonano na tryczkach rasy merynos polski o m.c. 20-25 kg, z przetokami do żwacza oraz mostkowymi przetokami do dwunastnicy i jelita biodrowego. Zwierzęta podzielono na dwie grupy żywione dietami izoazotowymi, ale różniącymi się zawartością włókna surowego (CF): (Grupa 1-14,7 a Grupa 2 - 24,9\% CF w s.m.). W wyniku większej zawartości włókna pobranie s.m. przez zwierzęta Grupy 2 było mniejsze niż w Grupie 1 (616 vs 467 g/d). Do obliczeń wykorzystano dane z naszych wspólnych doświadczeń (Sandek i wsp., 2001a), w których jedno ze zwierząt ( $\mathrm{Nr}$ l) było znakowane ${ }^{15} \mathrm{~N}$ przez infuzję do żwacza ${ }^{15} \mathrm{~N}$ mocznika. Treść dwunastnicy znakowanych owiec wymieniano z treścią owiec nie znakowanych ( $\mathrm{Nr} 2)$ przez 48 godzin i oznaczano przepływ $\mathrm{Ni}{ }^{15} \mathrm{~N}$ przez jelita; oznaczano również ilość $\mathrm{Ni}{ }^{15} \mathrm{~N}$ wydalanego w kale i moczu oraz wchłoniętego z jelit w tym okresie. Wykorzystując te dane obliczono parametry kinetyki obrotu białka stosując metodę końcowych produktów przemiany i trój-przedziałowy model.

Pobranie N (16,1 vs $11,7 \mathrm{~g} / \mathrm{szt}$./d w Grupie 1 i 2 ), absorpcja N netto (12,3 vs 7,3 g/szt./d w Grupie 1 i 2) i bilans N (104 vs -56 mg/kg m.c./d w Grupie 1 i 2) były istotnie większe w Grupie 1 niż 
$2(\mathrm{P}<0,10)$. Nie stwierdzono różnic w tempie przepływu (1666 vs $1458 \mathrm{mg} \mathrm{N} / \mathrm{kg} \mathrm{m} . \mathrm{c} . / \mathrm{d}$ ), syntezy (1238 vs $1087 \mathrm{mg} \mathrm{N} / \mathrm{kg} \mathrm{m.c./d)} \mathrm{i} \mathrm{degradacji} \mathrm{(1134} \mathrm{vs} 1324 \mathrm{mg} \mathrm{N} / \mathrm{kg}$ m.c./d) białka. Jednakże wydajność syntezy białka (bilans N/syntezy x 100) była istotnie większa $(\mathrm{P}<0,10)$ w Grupie 1 niż $2(8,8$ vs $5,2 \%)$. Wydajność syntezy białka była ujemnie skorelowana z sekrecją $\mathrm{N}$ w jelitach $(\mathrm{g} / \mathrm{kg}$ s.m. pobranej) $(r=-0,99 ; P<0,001)$ oraz z przepływem $\mathrm{N}$ endogennego przez jelito biodrowe $(\mathrm{g} / \mathrm{kg}$ s.m. pobranej) $(\mathrm{r}=-0,95 ; \mathrm{P}<0,0-1)$. Uzyskane wyniki wskazują, że sekrecja $\mathrm{N}$ w jelitach wpływa ujemnie na wydajność syntezy białka w ciele rosnących owiec, a mianowicie im większa sekrecja azotu w jelitach tym mniejsza jest wydajność syntezy białka. 